\title{
A Study of Uro-oncology Patient Perceptions of Social Support and Hope Levels
}

\author{
Arzu KOÇAK UYAROĞLU, ${ }^{1}$ Murat GÜL, ${ }^{2}$ Emine SARI, ${ }^{3}$ Serdar GÖKTAŞ ${ }^{4}$ \\ 'Department of Psychiatric Nursing, Selçuk University Faculty of Health Sciences, Konya-Turkey \\ ${ }^{2}$ Department of Urology, Van Training and Research Hospital, Üroloji Anabilim Dalı, Van-Turkey \\ ${ }^{3}$ Department of Public Health Nursing, Selçuk University Faculty of Health Sciences, Konya-Turkey \\ ${ }^{4}$ Department of Urology, Selçuk University Selçuklu Faculty of Medicine, Konya-Turkey
}

\begin{abstract}
OBJECTIVE
The present study measured social support perceptions and hope levels of uro-oncology patients diagnosed with cancer and examined how they vary according to sociodemographic variables.

METHODS

Research was conducted on 143 uro-oncology patients in Konya, Turkey, using a sociodemographic information form, the Multidimensional Scale of Perceived Social Support (MSPSS) and the Hope Scale.

\section{RESULTS}

Patient mean multidimensional perceived social support score was quite high at $62.14 \pm 14.99$, and mean hope level score was $20.62 \pm 4.50$. Hope level score was significantly higher in male patients. It was also higher for patients with dependents and for patients who believed their cancer was treatable. Perceived social support levels of patients with dependents and patients who believed their cancer was treatable were also significantly higher.
\end{abstract}

\section{CONCLUSION}

Hope levels of uro-oncology patients are affected positively by high levels of perceived social support. Women, patients with dependents, and patients who develop a positive attitude toward their cancer treatment were more hopeful than others.

Keywords: Cancer; hope; perceived social support.

Copyright $\odot$ 2016, Turkish Society for Radiation Oncology

\section{Introduction}

Cancer causes physical disabilities and psychosocial problems. There are short- and long-term compliance difficulties and periods of aggravation. According to the World Health Organization's (WHO) International Agency for Research on Cancer (IARC) data for 2012, there were 14.1 million new cancer cases and 8.2 million cancer deaths around the world. Some 8 million cancer cases occurred in developing countries.[1-3] In Turkey, roughly 175000 people were diagnosed with cancer in 2012. Of the newly diagnosed cases, two-thirds occurred in men and one-third occurred in women.[4] 
The most common urinary tract cancers in Turkey are prostate cancer, bladder cancer and renal cancer. The most frequent types of cancer diagnosed in males are prostate, lung and bladder cancers, respectively. However, breast cancer is more common than urinary tract cancers among females. The frequency of urinary tract cancers in males is 36.1 in 100000 for prostate cancer, 21.4 in 100000 for bladder cancer and 6.3 in 100000 for renal cancer. While the frequency of urinary tract cancers is 28.3 in 100000 for men, this frequency is only 6.5 for women. $[5,6]$

Cancer affects people physically, emotionally, and socially, and it causes important compliance problems and disorders. Cancer patients experience fear, despair, guilt, helplessness, excruciating pain, and fear of abandonment and death. These experiences vary with the progress of the stage of disease and individual reactions. Patients' individual care, maintenance of autonomy in terms of role functions, analysis of psychological and social compliance problems, individual patient support systems (family, friends, and healthcare workers), and improvement of functionality should all be included in the general principles and methods of teaching patients to live with cancer.[7,8]

Cancer diagnosis causes serious psychological social problems and workforce loss, not just for cancer patients, but also for their relatives and for society. Social support plays an important role in health promotion and in reducing pressure on cancer patients. Social support positively affects wellbeing, feelings of belonging, overcoming stress, physical health, and selfconfidence. $[9,10]$

The feelings that cancer patients experience are traumatic. This disease shakes patients' adaptation mechanisms and disrupts their expectations and plans. [11] During this traumatic experience, positive reactions of cancer patients affect their recovery period positively, and hope is an important positive reaction. [12] Hope has an important place in the adaptation of cancer patients to the disease and their compliance with treatment.[13] Hope can prevent pessimism and feelings of despair by improving cancer patients' motivation and contributing positive life energy.[14]

Professional healthcare workers have an important and vital role in cancer patients' acceptance process. This role in treatment and care facilitates patients' acceptance of treatment, accelerates their recovery, and positively affects their quality of life (QOL) by improving motivation and morale.[15] Psychosocial support is important to help cancer patients comply with treatment and improve their QOL.[16] To help patients ef- fectively, interventions that respond to the problems and needs of cancer patients should be planned using teamwork. Nurses who care for cancer patients should know that psychosocial support is an indispensable part of treatment and care, and they should be able to plan interventions to meet these needs.

This study was conducted to determine the social support perceptions and hope levels of uro-oncology patients in treatment for cancer, and to analyze how they vary according to sociodemographic variables such as age, gender, marital status, education, and employment status.

\section{Materials and Methods}

\section{Type of research}

This descriptive research using regression was carried out in the urology polyclinic of a hospital in Konya, Turkey, between June and August 2013.

\section{Population and sample of the study}

The study population included 160 uro-oncology patients being treated in the hospital unit. Of those, 143 were over 18 years of age, had no communication difficulties, agreed to participate in the research, and were included in the study sample.

\section{Data collection tools}

A questionnaire to record patients' socio-demographic characteristics and opinions on their disease, the Multidimensional Scale of Perceived Social Support (MSPSS), and the Hope Scale were used as data collection tools.

Questionnaire: The researchers developed the questionnaire after a review of the literature. It includes questions about patients' socio-demographic characteristics and information about their disease. $[7,17] \mathrm{Pa}-$ tients' age, gender, marital status, education, employment status, disease duration, number of dependents and belief about their disease being treatable were recorded using this form.

The Multidimensional Scale of Perceived Social Support (MSPSS): This scale was developed by Zimet et al. (1988).[18] This 12-item self-assessment scale measures the sufficiency of individuals' sources of social support. It is a 7-point Likert-type scale on which responses can range from "Strongly Disagree" (1) to "Strongly Agree" (7). This scale measures perceived sources of social support in 3 sub-dimensions including family, friends and significant other. The minimum 
possible score on the sub-scales is 4 , and the maximum is 28 . The minimum possible score on the entire scale is 12 , and the maximum is 84 . Higher scores indicate high levels of perceived social support. Validity and reliability analyses of the scale in Turkey were performed by Eker and Arkar (1995).[17] The Turkish version of the scale also consists of three sub-scales for sources of social support (family, friends, and significant other) and 12 items. The reliability factors of scale revised by Eker et al. (2001) were found to have high consistency levels, ranging from $0.80-0.95$. It is a valid and reliable tool.[19]

The Hope Scale: The Hope Scale was developed by Snyder et al. (1991) to measure the hope levels of people and was adapted to Turkish by Akman and Korkut (1993).[20,21] A study was conducted to determine reliability of the scale. Its internal consistency was assessed according to responses received by a group of 103 students at Hacettepe University, and its internal consistency coefficient was $.65(\mathrm{p}<001)$. This coefficient value was found adequate and the scale was administered twice, four weeks apart, to a group of 74 students at Hacettepe University Faculty of Education in the spring term of the 1991-1992 academic year. This 4-point Likert-type scale consists of 12 items. When scoring the scale, the filler items $(3,5,6,11)$ are ignored and a single score for each participant is obtained by adding scores on other items. Assessment is made using these scores. The minimum possible score on the scale is 8 , and the maximum is 32.[21]

\section{Ethical considerations}

Verbal consent was obtained from the uro-oncology patients after explaining the aim of the research to them. This study adhered to the principles of confidentiality and voluntary participation. The necessary permissions and ethics committee consent for the research were obtained from the hospital administration.

\section{Data assessment}

Statistical analyses were performed using SPSS software (version 21.0; SPSS Inc., Chicago, IL, USA). Percentages, averages and standard deviations were used to assess patients' sociodemographic characteristics and opinions on their disease. Mann-Whitney U test and Kruskal-Wallis test were used to assess their levels of social support and hope. Pearson's correlation test was used to examine differences between mean scores, and $\mathrm{p}<0.05$ was used as the threshold for significance.

\section{Results}

Men made up $84.6 \%$ of the participants, and $94.4 \%$ were married. Of the total, $64.4 \%$ had education level of primary school or less, and $68.5 \%$ were unemployed. It was found that $72.4 \%$ of the patients had dependents residing in their home, and $63.6 \%$ thought their cancer was treatable. The study found that in $90.9 \%$ of cases, the period of disease duration was in the 1 to 24 months interval, and that $81.1 \%$ of patients received the most support from their families (Table 1), compared to other sources of support.

The patients' mean MPSS multidimensional perceived social support score was $62.14 \pm 14.99$, and their mean hope level score was $20.62 \pm 4.50$. The male mean multidimensional perceived social support score and hope level mean score were determined to be $62.51 \pm 15.40$ and $21.14 \pm 4.40$, respectively. The female mean multidimensional perceived social support score

\begin{tabular}{|c|c|c|}
\hline Descriptive characteristics & $\mathrm{n}$ & $\%$ \\
\hline \multicolumn{3}{|l|}{ Gender } \\
\hline Male & 121 & 84.6 \\
\hline Female & 22 & 15.4 \\
\hline \multicolumn{3}{|l|}{ Marital status } \\
\hline Married & 135 & 94.4 \\
\hline Single & 8 & 5.6 \\
\hline \multicolumn{3}{|l|}{ Education } \\
\hline Illiterate & 4 & 2.8 \\
\hline Literate & 18 & 12.6 \\
\hline Primary school & 70 & 49.0 \\
\hline High school & 24 & 16.8 \\
\hline Associate's or Bachelor's Degree & 27 & 18.8 \\
\hline \multicolumn{3}{|l|}{ Working status } \\
\hline Working & 45 & 31.5 \\
\hline Not working & 98 & 68.5 \\
\hline \multicolumn{3}{|l|}{ Having a dependent } \\
\hline Yes & 104 & 72.4 \\
\hline No & 39 & 27.3 \\
\hline \multicolumn{3}{|l|}{ Duration of the disease } \\
\hline $1-24$ months & 130 & 90.9 \\
\hline 25 months and more & 13 & 9.1 \\
\hline \multicolumn{3}{|l|}{ Is the cancer treatable? } \\
\hline Yes, it is treatable & 91 & 63.6 \\
\hline No, it is not treatable & 52 & 36.4 \\
\hline \multicolumn{3}{|l|}{ People providing support to patient } \\
\hline Patient's family & 116 & 81.1 \\
\hline Only by herself/himself & 5 & 3.5 \\
\hline Patient's friends & 2 & 1.4 \\
\hline Health care workers & 7 & 4.9 \\
\hline $\begin{array}{l}\text { Family, friends and health care } \\
\text { workers together }\end{array}$ & 13 & 9.1 \\
\hline
\end{tabular}




\begin{tabular}{lccc} 
Table 2 & $\begin{array}{l}\text { Total sub-group mean scores on the MSPSS } \\
(n=143)\end{array}$ \\
& $\begin{array}{c}\text { Number of } \\
\text { items }\end{array}$ & Min.-Max. & Mean \pm SD \\
\hline Family & 4 & $4-28$ & $23.60 \pm 5.17$ \\
Friends & 4 & $4-28$ & $19.94 \pm 6.74$ \\
Significant other & 4 & $4-28$ & $23.60 \pm 5.17$ \\
Total & 12 & $12-84$ & $62.14 \pm 14.99$ \\
\hline
\end{tabular}

Min.: Minimum; Max.: Maximum; SD: Standard deviation. was found to be $60.09 \pm 12.61$, and their mean hope level score was $17.77 \pm 4.04$. The mean scores on the MSPSS were $23.60 \pm 5.17,19.94 \pm 6.74$ and $23.60 \pm 5.17$ for family, friends, and significant other sub-dimensions, respectively (Table 2).

The study did not find a significant difference between patient gender, marital status, education, duration of disease, belief that their cancer is treatable, employment status, number of dependents and support, and their multidimensional perceived social support

Table 3 The distribution of patients' scores on the multdimensional scale of perceived social support and the hope scale by their sociodemographic characteristics $(n=143)$

\begin{tabular}{|c|c|c|}
\hline Sociodemographic variables & $\begin{array}{l}\text { Multidimensional perceived } \\
\text { social support score }\end{array}$ & Hope score \\
\hline \multicolumn{3}{|l|}{ Gender } \\
\hline Female & $60.09 \pm 12.61$ & $17.77 \pm 4.04$ \\
\hline \multirow[t]{2}{*}{ Male } & $62.51 \pm 15.40$ & $21.15 \pm 4.40$ \\
\hline & $Z=-.955, p=0.340$ & $Z=-3.354, p=0.001$ \\
\hline \multicolumn{3}{|l|}{ Marital status } \\
\hline Married & $61.90 \pm 15.08$ & $20.63 \pm 4.47$ \\
\hline \multirow[t]{2}{*}{ Single } & $66.12 \pm 13.49$ & $20.50 \pm 5.37$ \\
\hline & $Z=-.646, p=0.518$ & $Z=-.207, p=0.836$ \\
\hline \multicolumn{3}{|l|}{ Education } \\
\hline Illiterate & $66.50 \pm 3.69$ & $19.00 \pm 2.82$ \\
\hline Literate & $59.66 \pm 13.14$ & $20.05 \pm 5.20$ \\
\hline Primary school & $60.42 \pm 17.25$ & $19.91 \pm 4.61$ \\
\hline High school & $62.91 \pm 13.46$ & $21.50 \pm 3.52$ \\
\hline \multirow[t]{2}{*}{ Associate's or Bachelor's Degree } & $66.88 \pm 11.11$ & $22.33 \pm 4.34$ \\
\hline & $\chi^{2}=4.72, p=0.137$ & $\chi^{2}=8.24, p=0.80$ \\
\hline \multicolumn{3}{|l|}{ Employment status } \\
\hline Working & $63.48 \pm 13.88$ & $21.31 \pm 4.08$ \\
\hline \multirow[t]{2}{*}{ Not working } & $61.52 \pm 15.50$ & $20.31 \pm 4.66$ \\
\hline & $Z=-.509, p=0.611$ & $Z=-1.184, p=0.236$ \\
\hline \multicolumn{3}{|l|}{ Dependents } \\
\hline Yes & $62.93 \pm 14.69$ & $21.08 \pm 4.66$ \\
\hline \multirow[t]{2}{*}{ No } & $60.02 \pm 15.75$ & $19.41 \pm 3.82$ \\
\hline & $Z=-1.084, p=0.278$ & $Z=-2.422, p=0.015$ \\
\hline \multicolumn{3}{|l|}{ Duration of disease } \\
\hline $1-24$ months & $62.54 \pm 14.73$ & $20.50 \pm 4.60$ \\
\hline \multirow[t]{2}{*}{25 months and more } & $60.67 \pm 16.04$ & $21.09 \pm 4.17$ \\
\hline & $Z=-.586, p=0.558$ & $Z=-.587, p=0.557$ \\
\hline \multicolumn{3}{|l|}{ Is the cancer treatable? } \\
\hline Yes, it is treatable & $62.93 \pm 16.56$ & $21.67 \pm 4.16$ \\
\hline \multirow[t]{2}{*}{ No, it is treatable } & $60.75 \pm 11.77$ & $18.80 \pm 4.53$ \\
\hline & $Z=-1.400, p=0.161$ & $Z=-3.987, p=0.000$ \\
\hline \multicolumn{3}{|l|}{ People providing support to patient } \\
\hline Family & $61.51 \pm 15.16$ & $20.49 \pm 4.78$ \\
\hline Only self-support & $65.60 \pm 17.12$ & $18.20 \pm 1.92$ \\
\hline Friends & $60.00 \pm 2.82$ & $20.00 \pm 2.82$ \\
\hline Healthcare workers & $69.57 \pm 13.04$ & $20.42 \pm 2.99$ \\
\hline Family, friends and health care workers together & $\chi^{2}=2.224, p=0.695$ & $\chi^{2}=7.068, p=0.132$ \\
\hline
\end{tabular}


scores ( $p>0.05)$. Univariate analysis of mean hope level score found it to be significantly higher in male patients $(\mathrm{Z}=-3.354 ; \mathrm{p}=0.001)$ than female patients. It was also higher for patients with dependents $(Z=-2.422$; $\mathrm{p}=0.015)$ and for patients who believed their cancer was treatable $(\mathrm{Z}=-3.987 ; \mathrm{p}=0.000)$ (Table 3$)$.

According to the distribution of sub-dimension scores by sociodemographic characteristics, perceived social support levels of both patients with dependents and patients who believed their cancer was treatable
Table 5 The distribution of the relationship between patients' hope scores and multidimensional perceived social support scores

\begin{tabular}{lc}
\hline & Hope score $(20.62 \pm 4.50)$ \\
\hline Multidimensional perceived & $\mathrm{n}=143$ \\
social support score & $\mathrm{r}=0.132$ \\
$(62.13 \pm 14.99)$ & $\mathrm{p}=0.115$ \\
\hline
\end{tabular}

were significantly higher $(\mathrm{Z}=-2.071, \mathrm{p}=0.038 ; \mathrm{Z}=$ 4.020, $\mathrm{p}=0.000)$ (Table 4).

Table 4 The distribution of patients' sub-dimension scores on the MSPSS by their sociodemographic characteristics

\begin{tabular}{|c|c|c|c|c|}
\hline \multirow[t]{2}{*}{ Sociodemographic characteristics } & \multirow[t]{2}{*}{$\mathrm{n}$} & Family & \multirow{2}{*}{$\frac{\text { Friend }}{\text { Mean } \pm S D}$} & \multirow{2}{*}{$\frac{\text { Significant other }}{\text { Mean } \pm S D}$} \\
\hline & & Mean \pm SD & & \\
\hline \multicolumn{5}{|l|}{ Gender } \\
\hline Female & 22 & $22.40 \pm 4.00$ & $9.86 \pm 6.31$ & $17.81 \pm 6.58$ \\
\hline \multirow[t]{2}{*}{ Male } & 121 & $23.82 \pm 5.33$ & $19.95 \pm 6.85$ & $18.72 \pm 7.92$ \\
\hline & & $Z=-1.921, p=0.055$ & $Z=-.267, p=0.790$ & $Z=-.935, p=0.350$ \\
\hline \multicolumn{5}{|l|}{ Marital status } \\
\hline Married & 135 & $23.64 \pm 5.19$ & $19.75 \pm 6.83$ & $23.54 \pm 5.19$ \\
\hline \multirow[t]{2}{*}{ Single } & 8 & $23.00 \pm 4.98$ & $23.12 \pm 4.15$ & $23.00 \pm 4.98$ \\
\hline & & $Z=-.404, p=0.656$ & $Z=-1.222, p=0.222$ & $Z=-.370, p=0.711$ \\
\hline \multicolumn{5}{|l|}{ Education } \\
\hline Illiterate & 4 & $25.25 \pm 2.50$ & $18.75 \pm 3.77$ & $22.50 \pm 1.91$ \\
\hline Literate & 18 & $24.00 \pm 4.56$ & $19.88 \pm 7.35$ & $15.77 \pm 9.04$ \\
\hline Primary school & 70 & $23.14 \pm 6.06$ & $18.84 \pm 7.42$ & $18.44 \pm 7.70$ \\
\hline High school & 24 & $23.79 \pm 3.91$ & $20.62 \pm 6.30$ & $18.50 \pm 7.84$ \\
\hline \multirow[t]{2}{*}{ Associate's or Bachelor's Degree } & 27 & $24.14 \pm 4.36$ & $22.40 \pm 4.46$ & $20.33 \pm 6.22$ \\
\hline & & $\chi^{2}=0.430, p=0.980$ & $\chi^{2}=4.647, p=0.325$ & $\chi^{2}=3.286, p=0.511$ \\
\hline \multicolumn{5}{|l|}{ Employment status } \\
\hline Working & 45 & $24.22 \pm 3.98$ & $20.60 \pm 6.78$ & $18.66 \pm 7.17$ \\
\hline \multirow[t]{2}{*}{ Not working } & 98 & $23.32 \pm 5.62$ & $19.64 \pm 6.74$ & $18.55 \pm 7.82$ \\
\hline & & $Z=-.029, p=0.977$ & $Z=-.746, p=0.455$ & $Z=-.161, p=0.872$ \\
\hline \multicolumn{5}{|l|}{ Dependens } \\
\hline Yes & 104 & $24.07 \pm 5.02$ & $20.07 \pm 6.75$ & $18.77 \pm 7.67$ \\
\hline \multirow[t]{2}{*}{ No } & 39 & $22.35 \pm 5.41$ & $19.58 \pm 6.80$ & $18.07 \pm 7.49$ \\
\hline & & $Z=-2.071, p=0.038$ & $Z=-.382, p=0.702$ & $Z=-.717, p=0.474$ \\
\hline \multicolumn{5}{|l|}{ Duration of disease } \\
\hline $1-24$ months & 130 & $23.44 \pm 5.20$ & $20.22 \pm 6.81$ & $18.86 \pm 7.35$ \\
\hline \multirow[t]{2}{*}{25 months or more } & 13 & $24.84 \pm 4.84$ & $17.23 \pm 5.93$ & $15.15 \pm 9.37$ \\
\hline & & $Z=-.676, p=0.499$ & $Z=-1.296, p=0.195$ & $Z=-.767, p=0.443$ \\
\hline \multicolumn{5}{|l|}{ Is the cancer treatable? } \\
\hline Yes, it is treatable & 91 & $24.54 \pm 5.35$ & $9.69 \pm 7.24$ & $18.69 \pm 8.16$ \\
\hline \multirow[t]{2}{*}{ No, it is not treatable } & 52 & $21.96 \pm 4.41$ & $20.38 \pm 5.31$ & $18.40 \pm 6.57$ \\
\hline & & $Z=-4.020, p=0.000$ & $Z=-.048, p=0.961$ & $Z=-.779, p=0.436$ \\
\hline \multicolumn{5}{|l|}{ People supporting the patient } \\
\hline Family & 116 & $23.60 \pm 5.37$ & $19.56 \pm 7.00$ & $18.35 \pm 7.60$ \\
\hline Only self-support & 5 & $21.80 \pm 5.63$ & $20.80 \pm 6.73$ & $23.00 \pm 4.84$ \\
\hline Friends & 2 & $20.00 \pm 2.82$ & $20.50 \pm 0.70$ & $19.50 \pm 4.94$ \\
\hline Healthcare workers & 7 & $24.00 \pm 4.72$ & $24.28 \pm 4.34$ & $21.28 \pm 6.12$ \\
\hline \multirow[t]{2}{*}{ Family, friends, healthcare workers together } & 13 & $24.69 \pm 3.49$ & $20.61 \pm 5.50$ & $17.38 \pm 9.32$ \\
\hline & & $\chi^{2}=2.766, p=0.598$ & $\chi^{2}=3.494, p=0.479$ & $\chi^{2}=2.443, p=0.655$ \\
\hline
\end{tabular}


A very slight correlation was found between the uro-oncology patients' multidimensional perceived social support scores and their hope level scores $(r=0.132$; $\mathrm{p}=0.115$ ) (Table 5).

\section{Discussion}

Patients' mean multidimensional perceived social support score was relatively high at $62.14 \pm 14.99$ on a scale of 12 to 84 . Dedeli et al. (2008) conducted a study that found cancer patients' scores on a social support scale to be high.[22] Similarly, Tan et al. (2005) carried out a study with hemodialysis patients, and Arslantas et al. (2010) conducted a study with in-patients, and they both found that patients' mean social support scores were more than moderate and close to the high level. $[23,24]$ Social support for cancer patients was mostly provided by their families. Although there is currently a transition from extended to nuclear families, strong family ties and the participants' characteristics may be a factor in high scores on perceived social support scale. Social support is an important variable, especially for physical and psychological adaptation of cancer patients. Landmark et al. (2002) carried out a study of women with breast cancer and determined that their most important sources of social support were their families and their friends.[25] A similar study found that Iranian cancer patients' perceptions of social support were at high levels, and that their main source of support was family members. [26]

The current study also determined that hope level scores of uro-oncology patients were more than moderately high. Aslan et al. (2007) conducted a study to determine hope levels of cancer patients and found that their hope scores were higher than moderate level.[27] Jo and Son's study (2004) of cancer patients' QOL, hope, and uncertainty found a similar result.[28] Arslantaş et al. (2010) also found moderate levels of hope in a study conducted with in-patients. [24] The results of the present study and other research are similar.[24,27,28] Hope levels of patients are higher than moderate level when they were expected to be low. Hope scores may have been higher than moderate level because hope is a factor that improves motivation for treatment.

Hope scores of male patients were higher than those of female patients, and the difference was significant. Most studies have similarly found that hope levels of cancer patients did not differ by gender.[27,29] Moreover, patients' mean hope level scores were high for those with dependents and those who think their cancer is treatable. Knowledge about cancer is impor- tant to reduce patient fears and to eliminate doubts. Patients who think they will die from cancer will understand that cancer is treatable if they are given accurate information. Most studies show that hope levels of cancer patients who have adequate knowledge about cancer are high. This makes knowledge important for coping with cancer and the emotional problems it causes.[30,31]

Social support is one of the most important factors in the hope levels of cancer patients. Social support and hope are important sources of positive thinking. There are some studies showing that as patient social support levels increase, so do their hope levels.[32-34] Unlike these studies, Fadiloğlu et al. (2006) conducted a study of the relationship between hopelessness levels of women with breast cancer and their coping behaviors and determined that social support had no effect on levels of hopelessness.[35] The present study found a very slight correlation between multidimensional perceived social support scores and hope scores, although both are above moderate level. This result may be due to the characteristics of the participants and the small sample size.

\section{Conclusion}

The uro-oncology patients' high levels of perceived social support, their positive attitude about cancer and their responsibilities positively affect hope levels. The study determined a positive and slight relationship between patients' perceived social support and hope levels. Thus, the study suggests that:

- social support and hope levels of cancer patients should be determined and programs should be implemented to improve them;

- cooperation with patient's family should be promoted and family members should be included in treatment;

- patients should be informed about disease process, treatment, and coping strategies, and sharing groups should be formed;

- studies of the relationship between cultural features, hope, and perception of social support, and qualitative studies that thoroughly research these issues should be planned and conducted.

\section{Conflict of interest: None declared.}

\section{References}

1. Barber FD. Social support and physical activity engagement by cancer survivors. Clin J Oncol Nurs 
2012;16:84-9.

2. Holland CJ, Weiss RT. History of psycho-oncology. In: Holland JC, Breitbart WS, Jacobsen PB, Lederberg MS, Loscalzo MJ, Mc Corkle RS, editors. Psycho-oncology. 2nd ed. New York: Oxford University Press; 2010. p. 3-11.

3. American Cancer Society. Global Cancer Facts \& F igures 3rd edition. Atlanta: American Cancer Society. 2015. http://www.cancer.org/acs/groups/content/@research/documents/document/acspc-044738.pdf [Access date: 12.12.2015].

4. T.C. Sağlık Bakanlığı, Türkiye Halk Sağlığı Kurumu Kanser İstatistikleri. http://kanser.gov.tr/ Dosya/2015haberler1/Kanser_insidanslari_2012_ kisa_rapor.pdf [Access date: 15.03.2015].

5. Aydın S, Boz MY. Rapid changes in the incidence of urinary system cancers in Turkey. Turk J Urol 2015;41(4):215-20.

6. Sağlık Bakanlığı, Türkiye Halk Sağlı̆̆ı Kurumu Kanser İstatistikleri. http://kanser.gov.tr/ Dosya/2015haberler1/Kanser_insidanslari_2012_ kisa_rapor.pdf [Access date: 15.03.2015].

7. Ülger E, Alacacıoğlu A, Gülseren AŞ, Zencir G, Demir L, Tarhan MO. Psychosocial problems in cancer and the importance of psychosocial oncology. DEÜ Tip Fakültesi Dergisi 2014;28(2):85-92.

8. Anuk $\mathrm{D}$, Özkan $\mathrm{M}$, Alçalar N. İstanbul Üniversitesi Konsültasyon Liyezon Psikiyatrisi Bilim Dalı Psikoonkoloji çalışmalarının 2 yıllık dökümü. 5. Ulusal Konsültasyon Liyezon Psikiyatrisi Kongre Kitabı, İstanbul. 1999. s. 174-81.

9. T.C. Sağlık Bakanlığı Tedavi Hizmetleri Genel Müdürlüğü Türkiye Onkoloji Hizmetleri Yeniden Yapilanma Programı 2010-2023. http://www.rivosem.com.tr/wp-content/ uploads/2015/04/T\%C3\%BCrkiye-OnkolojiHizmetleri-Yeniden-Yap\%C4\%B1land\%C4\%B1rmaProgram\%C4\%B1.pdf. [Access date: 10.12.2015].

10. Firshein R. Life Support. Psychology today. 1999;32(4):28-9.

11. Işıkhan V. Kanser ve yaşam kalitesi. Nihal Turan’a armağan: Sosyal hizmetlerde yeni yaklaşımlar ve sorun alanları. Editör: Duyan V, Mavili Aktaş A. Ankara: 1999. s. 171.

12. Eliott JA, Olver IN. Hope and hoping in the talk of dying cancer patients. Soc Sci Med 2007;64(1):138-49.

13. Chen ML. Pain and hope in patients with cancer: a role for cognition. Cancer Nurs 2003;26(1):61-7.

14. Öz F. Sağlık alanında temel kavramlar. İmaj İç ve Dış A.Ş. Ankara: 2004.

15. Dean A. Talking to dying patients of their hopes and needs. Nurs Times 2002;98(43):34-5.
16. Elbi MH. Kanserde anksiyete bozuklukları ve depresyon dahiliye ve psikiyatri VI, I. Basım. İstanbul: Okuyanus Yayın; 2004.

17. Eker D, Arkar H. Çok boyutlu algılanan sosyal destek ölçeğinin faktör yapısı, geçerlik ve güvenirliği. Türk Psikoloji Dergisi 1995;10:45-55.

18. Zimet GD, Dahlem NW, Zimet SG, Farley GK. The Multidimensional Scale of Perceived Social Support. Journal of PersonalityAssessment 1998;52:30-41.

19. Eker D, Arkar H, Yaldız H. Factorial Structure, Validity, and Reliability of Revised Form of the Multidimensional Scale of Perceived Social Support. Türk Psikiyatri Dergisi 2001;12(1):17-25.

20. Snyder CR, Harris C, Anderson JR, Holleran SA, Irving LM, Sigmon ST, et al. The will and the ways: development and validation of an individual-differences measure of hope. J Pers Soc Psychol 1991;60(4):57085.

21. Akman Y, Korkut F. Umut ölçeği üzerine bir çalışma. Hacettepe Üniversitesi Eğitim Fakültesi Dergisi 1993;9:193-202.

22. Dedeli Ö, Fadıloğlu Ç, Uslu R. A survey of functional living and social support in patients with cancer. Turk J Oncol 2008;23(3):132-9.

23. Tan M, Okanlı A, Karabulutlu E, Erdem N. The Evaluation of Relationship Between Social Support and Hopelessness in Hemodialysis Patients. Atatürk Üniversitesi Hemşirelik Yüksekokulu Dergisi 2005;8(2):32-9.

24. Arslantaş H, Adana F, Kaya F, Turan D. Hopelessness and Social Support Level in The Inpatients and Factors Affecting Them. İ.Ü.F.N. Hemşirelik Dergisi 2010;18(2):87-97.

25. Landmark BT, Strandmark M, Wahl A. Breast cancer and experiences of social support. In-depth interviews of 10 women with newly diagnosed breast cancer. Scand J Caring Sci 2002;16(3):216-23.

26. Faghani S, Rahmani A, Parizad N, Mohajjel-Aghdam AR, Hassankhani H, Mohammadpoorasl A. Social support and its predictors among Iranian cancer survivors. Asian Pac J Cancer Prev 2014;15(22):9767-71.

27. Aslan Ö, Sekmen K, Kömürcü Ş, Özet A. Kanserli Hastalarda Umut. C.Ü. Hemşirelik Yüksekokulu Dergisi 2007;11(2):18-24.

28. Jo KH, Son BK. The relationship of uncertainty, hope and quality of life in patients with breast cancer. [Article in Korean] Taehan Kanho Hakhoe Chi 2004;34(7):1184-93. [Abstract]

29. Özdaş T, Olgun N. Hopelessness Levels of Bone Marrow Transplant Patients and The Affecting Factors. Sağlık Bilimleri ve Meslekleri Dergisi 2015;2(1):12-21.

30. Lin CC, Tsai HF, Chiou JF, Lai YH, Kao CC, Tsou TS. Changes in levels of hope after diagnostic disclosure 
among Taiwanese patients with cancer. Cancer Nurs 2003;26(2):155-60.

31. Irving LM, Snyder CR, Crowson JJ Jr. Hope and coping with cancer by college women. J Pers 1998;66(2):195214.

32. Dansuk R, Ağargün M, Kars B, Ağargün HP, Turan C, Ünal O. Evaluation of the Psychosocial Characteristics of Gyneacologic Cancer Patients. Türkiye Klinikleri Journal of Gynecology and Obstetrics 2002;12(2);142-7.

33. Crothers MK, Tomter HD, Garske JP. The relation- ships between satisfaction with social support, affect balance, and hope in cancer patients. J Psychosoc Oncol 2005;23(4):103-18.

34. Vellone E, Rega ML, Galletti C, Cohen MZ. Hope and related variables in Italian cancer patients. Cancer Nurs 2006;29(5):356-66.

35. Fadıloğlu Ç, Cantilav Ş, Yıldırım YK, Tokem Y. The relationship between hopelessness and coping strategies with breast cancer women. Ege Üniversitesi Hemşirelik Yüksekokulu Dergisi 2006;22(2):147-60. 